\title{
ANALISIS METODE ECONOMIC ORDER QUANTITY (EOQ) DAN ANALISIS KLASIFIKASI ABC SERTA ANALISIS VITAL, ESENSIAL DAN NON ESENSIAL (VEN) TERHADAP PERSEDIAAN OBAT
}

\author{
Mohammad Benny Alexandri ${ }^{1}$, Meita Pragiwani ${ }^{2}$, Inayah $^{3}$ \\ ${ }^{1}$ Universitas Padjadjaran \\ ${ }^{2,3}$ Sekolah Tinggi Ekonomi Indonesia \\ mohammad.benny@unpad.ac.id¹, meitasoetopo@gmail.com²,malikiinayah@gmail.com³
}

\begin{abstract}
ABSTRAK
Penelitian ini memiliki tujuan (1) Bagaimana sistem penentuan persedian obat di Klinik-Apotek Dharma Tangerang., (2) Bagaimana analisis metode economic order quantity (EOQ) terhadap penentuan persediaan obat di Klinik Apotek Dharma Tangerang. (3) Bagaimana analisis klasifikasi ABC terhadap penentuan persediaan obat pada Klinik Apotek Dharma Tangerang. (4) Bagaimana metode analisis vital, esensial dan non esensial (VEN) terhadap penentuan persediaan obat pada Klinik Apotek Dharma Tangerang. Jenis penelitian ini adalah deskriptif kuantitatif dengan memaparkan bagaimana pengendalian persediaan obat yang diterapkan di Klinik Apotek Dharma Tangerang. Lewat data yang diperoleh akan dianalisis menggunakan metode economic order quantity (EOQ), metode analisis klasifikasi ABC dan analisis vital, esensial dan non esensial (VEN).Hasil penelitian ini Pada penggunaan analisis klasifikasi ABC berdasarkan nilai investasi dapat diketahui kelompok A dari golongan obat vital 69,83\% dengan volume 17 unit, golongan obat esensial 70,23\% dengan volume 13 unit dan golongan non esensial 70,69\% dengan volume 6 unit.Kelompok B dari golongan obat vital 20,16\% volume 18 unit, golongan obat esensial 19,24\% dengan volume 14 unit dan golongan non esensial 17,88\% dengan volume 7 unit. Kelompok C golongan vital 10,01\% volume 31 unit, esensial 10,53\% dengan volume 31 unit dan golongan non esensial 9,48\% dengan volume 23 unit. Dengan metode EOQ dalam pengadaan sediaan obat biaya pembelian unit obat untuk golongan obat vital Rp 1.069.223.104 dengan nilai EOQ terendah 1 dan tertinggi 105, untuk golongan obat esensial Rp. 280.472.456 nilai EOQ terendah 1 dan tertinggi 41, dan golongan obat non esensial Rp. 148.042.836 dengan nilai EOQ terendah 1 dan tertinggi 58.
\end{abstract}

Kata kunci : EOQ, Klasifikasi ABC, Vital, Esensial dan Non Esensial

\section{PENDAHULUAN}

Pelayananan kesehatan masyarakat secara merata menjadi tanggung jawab pemerintah, swasta dan masyarakat. Berkembangnya ilmu pengetahuan dan teknologi yang semakin modern membuat persaingan antar perusahaan semakin ketat. Menghadapi era persaingan yang ketat ini maka yang perlu diperhatikan dalam layanan kesehatan masyarakat adalah tempat layanan kesehatan masyarakat itu sendiri.

Dunia farmasi khususnya apotek merupakan lahan bisnis yang menguntungkan dan membuat orang tertarik untuk melakukan investasi di dalamnya. Hal ini wajar, mengingat 
dunia kesehatan sepertinya tidak pernah sepi karena merupakan salah satu kebutuhan masyarakat yang penting. Hal tersebut juga ditunjang dengan adanya kenyataan bahwa permintaan obat dari tahun ke tahun semakin meningkat seiring dengan kesadaran masyarakat akan pentingnya kesehatan (Anief, M. 2014)

Realitas ini kemudian membuat banyak investor menanamkan modalnya ke apotek. Akan tetapi tidak sedikit diantara mereka yang merugi dan gulung tikar dikarenakan manajemen pengelolan yang buruk, oleh karena itu pengelolaan persediaan di apotek harus benar-benar diperhatikan mulai dari pengelolaan operasinal, perencanaan sampai dengan pengadaannya dengan baik agar dapat bertahan dan bersaing mempertahankan pasar yang sudah ada (Anief, M. 2014).

Menurut data Kementerian Kesehatan dari BBPOM jumlah apotek di provinsi Banten tahun 2016 ada 1375 unit, sekitar 5,13\% dari jumlah apotek di Indonesia (26.803 unit), tahun 2017 ada 1402 unit, sekitar 5,42\% dari apotek di Indonesia (25.867 unit), tahun 2018 ada 1442 unit, sekitar 5,79 \% dari jumlah apotek di Indonesia (24.905 unit) dan tahun 2019 ada 1251 unit sekitar 4,98\% dari jumlah apotek di Indonesia (25.120 unit) (BBPOM, 2019).

Menurut Permenkes No. 9 tahun 2014 klinik adalah fasilitas pelayanan kesehatan yang menyelenggarakan pelayanan kesehatan perorangan yang menyediakan pelayanan medis dasar dan atau spesialistik. Klinik yang dimiliki oleh masyarakat yang menyelenggarakan rawat jalan dapat didirikan oleh perorangan atau badan usaha. Klinik yang menyelenggarakan pelayanan kesehatan harus menyediakan dokter serta tenaga kesehatan lain sesuai dengan kebutuhan pelayanan dan setiap saat berada di tempat. Klinik rawat jalan tidak wajib memiliki pelayanan kefarmasian. Klinik rawat jalan yang menyelenggarakan pelayanan kefarmasian wajib memiliki apoteker yang memiliki Surat Izin Praktek Apoteker (SIPA) sebagai penanggung jawab atau pendamping. Apotek adalah sarana pelayanan kefarmasian tempat dilakukannya praktik kefarmasian oleh apoteker (Kementerian Kesehatan, 2014).

Pelayanan kefarmasian di apotek salah satunya adalah pengadaan yaitu kegiatan yang dimaksudkan untuk perencanaan kebutuhan. Pengadaan yang efektif harus menjamin ketersediaan, jumlah dan waktu yang tepat dengan harga yang terjangkau dan sesuai dengan standar mutu. Pengadaan merupakan kegiatan yang berkesinambungan mulai dari pemilihan, penentuan jumlah yang dibutuhkan juga penyesuaian antara kebutuhan dan dana (Anief, M. 2014). Manajemen persediaan obat bertujuan untuk membentuk suatu sistem yang merespon kebutuhan actual pasien. Economic Order Quantity (EOQ) adalah pemodelan matematika yang paling banyak digunakan untuk manajemen persediaan obat. Model EOQ digunakan untuk menghitung pemesanan dengan biaya optimum dan seimbang antara biaya persediaan dan biaya tambahan. Pendekatan matematika lainnya adalah peramalan permintaan dan waktu pemesanan kembali Re-Order Point (ROP) untuk memperkirakan Safety Stock (SS) atau jumlah persediaan yang memadai (Quick, et al, 2012).

Dalam menganalisis pola konsumsi perbekalan farmasi yang biasa digunakan adalah Analisis Klasifikasi 
ABC atau Pareto. Sementara analisis VEN (Vital, Esential, Non-Esensial) adalah suatu sistem untuk menentukan seleksi, pengadaan dan penggunaan perbekalan farmasi. Untuk menghindari stock out atau kekosongan dan memperbesar manfaat dana yang tersedia dapat dikontrol dengan analisis VEN. Dengan demikian gabungan analisis klasifikasi ABC dan VEN dapat digunakan untuk mengevaluasi pola pengadaan dengan dasar prioritas (Bachrun, E.2017).

Berdasarkan latar belakang tersebut dapat dirumuskan masalah penelitian sebagai berikut :

1. Bagaimana analisis metode economic order quantity (EOQ) terhadap penentuan persediaan obat di Klinik Apotek Dharma Tangerang.

2. Bagaimana analisis klasifikasi ABC terhadap penentuan persediaan obat pada Klinik Apotek Dharma Tangerang.

3. Bagaimana metode analisis vital, esensial dan non esensial (VEN) terhadap penentuan persediaan obat pada Klinik Apotek Dharma Tangerang.

4. Bagaimana sistem penentuan persedian obat di Klinik Apotek Dharma Tangerang

\section{TINJAUAN PUSTAKA}

\section{Fungsi Persediaan}

Persediaan dapat memiliki berbagai fungsi penting yang menambah fleksibilitas dari operasi suatu perusahaan. Fungsi persediaan persediaan (Heizer dan Render, 2016: 554) yaitu:

1. Untuk memberikan pilihan barang agar dapat memenuhi permintaan pelanggan yang diantisipasi dan memisahkan perusahaan dari fluktuasi permintaan. Persediaan ini digunakan secara umum pada perusahaan ritel.

2. Untuk memisahkan beberapa tahapan dari proses produksi. Contohnya jika persediaan sebuah perusahaan berfluktuasi, persediaan tambahan mungkin diperlukan agar bisa memisahkan proses produksi dan pemasok.

3. Untuk mengambil keuntungan dari potongan jumlah karena pembelian dalam jumlah besar dapat menurunkan pengiriman biaya barang.

4. Untuk menghindari inflasi dan kenaikan harga.

\section{Model Dasar Economic Order Quantity (EOQ)}

Model kuantitas pesanan ekonomis dasar (economic order quantity-EOQ) adalah salah satu teknik pengendalian persediaan yang paling sering digunakan. Metode EOQ merupakan metode yang bertujuan untuk mendapatkan tingkat order yang bersifat tetap besarannya. Karena bertujuan untuk mendapatkan tingkat besaran order yang tetap, maka metode ini berusaha untuk mendapatkan tingkat besaran order yang optimal, 
jumlahnya mengacu kepada keuangan yang dihadapi oleh perusahaan. Pada perhitungan ini faktor waktu tunggu (Lead Time) diperhitungkan untuk meletakkan titik order kembali berdasarkan jumlah optimal yang telah diperhitungkan sebelumnya sehingga datangnya order tepat waktu untuk mengantisipasi permintaan yang muncul (Heizer dan Render, 2016:562).

Model persediaan umumnya bertujuan untuk meminimalkan total biaya. Biaya yang paling signifikan adalah biaya pemasangan atau pemesanan dan biaya penyimpanan atau membawa persediaan. Semua biaya lain seperti biaya persediaan itu sendiri, bersifat konstan. Dengan meminimalkan jumlah pemasangan dan penyimpanan, maka akan meminimalkan total biaya. Ukuran pesanan optimal $\mathrm{Q}^{*}$ adalah jumlah pesanan yang meminimalkan total biaya. Seiring dengan meningkatnya kuantitas yang dipesan akan menurun pesanan per tahunnya. Dengan meningkatnya kuantitas yang dipesan, biaya pemasangan atau pemesanan per tahun akan menurun. Akan tetapi, dengan meningkatnya kuantitas yang dipesan, biaya penyimpanan akan meningkat karena jumlah rata-rata persediaan yang diurus lebih banyak (Heizer dan Render, 2016:562).

\section{Analisis Vital, Esensial dan Non Esensial (VEN)}

Analisis vital, esensial dan non esensial merupakan salah satu cara untuk meningkatkan efisiensi penggunaan dana obat yang terbatas adalah dengan menggelompokkan obat yang didasarkan kepada dampak tiap jenis obat pada kesehatan (Departemen Kesehatan RI., 2010)

Analisis vital, esensial dan non esensial digunakan untuk membuat prioritas pembelian obat-obatan dan untuk menjaga persediaan. Obatobatan dibagi berdasarkan dampaknya pada kesehatan yaitu Vital (V), Esensial (E) dan Non-Esensial (N) (Departemen Kesehatan RI., 2010).

\section{Kelompok V}

Kelompok $\mathrm{V}$ adalah kelompok obatobatan yang sangat esensial (vital), yang termasuk kelompok ini antara lain

- Obat penyelamat hidup (life saving drug)

- Obat-obatan untuk pelayanan kesehatan pokok (vaksin dan lain-lain).

- Obat-obatan untuk mengatasi penyakitpenyakit penyebab kematian terbesar.

\section{Kelompok E}

Kelompok E adalah kelompok obatobatan yang bersifat kausal yaitu obat yang efektif dan signifikan bekerja pada sumber penyakit tetapi tidak sepenting obat vital untuk disediakan.

\section{Kelompok N}

Kelompok $\mathrm{N}$ merupakan obat penunjang yaitu obat yang bekerjanya ringan adan biasa dipergunakan untuk menimbulkan kenyamanan atau untuk mengatasi keluhan ringan atau penyakit yang dapat diatasi sendiri. Termasuk kelompok berkhasiat namaun tidak terlalu penting untuk disediakan.

\section{METODOLOGI PENELITIAN}

Dalam penelitian ini, strategi yang digunakan adalah deskriptif kuantitatif. Penelitian desktiptif adalah penelitian yang dilakukan untuk mengetahui keberadaan variabel 
mandiri (variabel yang berdiri sendiri), baik satu variabel atau lebih variabel tanpa membuat perbandingan atau mencari hubungan variabel satu sama lain (Sugiyono, 2016:29).

Jenis penelitian ini adalah deskriptif kuantitatif dengan memaparkan bagaimana pengendalian persediaan obat yang diterapkan di Klinik Apotek Dharma Tangerang. Lewat data yang diperoleh akan dianalisis menggunakan metode economic order quantity (EOQ), metode analisis klasifikasi ABC dan analisis vital, esensial dan non esensial (VEN). Jadi metode penelitian ini mengukur atau menghitung angka persediaan optimal suatu obat yang hasilnya disajikan berupa data berbentuk angka dan ditafsirkan dalam kalimat kualitatif.

Pada penelitian ini juga dilakukan metode klasifikasi vital, esennsial dan non esensial (VEN). Metode analisis VEN merupakan penggelompokan obat berdasarkan kepada dampak tiap jenis obat terhadap kesehatan. Semua jenis obat yang direncanakan dikelompokan ke dalam tiga kategori yakni (Febriawati, H, 2013) :

\section{Vital}

Obat-obat yang harus tersedia untuk melayani permintaan guna penyelamatan hidup manusia, atau untuk pengobatan karena penyakitnya tersebut dapat menyebabkan kematian (life saving).

\section{Esensial (E)}

Obat-obatan yang banyak diminta untuk digunakan dalam tindakan atau pengobatan penyakit terbanyak yang ada disuatu daerah atau rumah sakit.

\section{Non Esensial (N)}

Obat-obat pelengkap agar tindakan atau pengobatan menjadi lebih baik. Obat kelompok $\mathrm{N}$ digunakan untuk mengatasi sebagian kecil penyakit atau penyakit yang dapat diatasi sendiri, termasuk kelompok berkhasiat namun tidak terlalu penting.

\section{DISKUSI}

1. Bagaimana analisis metode economic order quantity (EOQ) terhadap penentuan persediaan obat di Klinik Apotek Dharma Tangerang.

Persediaan obat di Klinik Apotek Dharma dilakukan oleh bagian pengadaan dan gudang farmasi dibawah pengawasan Apoteker Penanggung Jawab Apotek dengan anggaran biaya yang disetujui oleh Pemilik Sarana Klinik Apotek. Agar ketersediaan obat dapat berjalan dengan baik yaitu dengan jumlah yang tepat dan dengan biaya yang serendahrendahnya maka bagian pengadaan dan gudang farmasi berupaya melakukan pengendalian dengan baik.

Pengendalian persediaan yang dilakukan oleh bagian pengadaan dan gudang farmasi Klinik Apotek Dharma adalah dengan melakukan stock opname, pencatatan pada kartu stok dan buku defekta. Stock opname di Klinik Apotek Dharma dilakukan setiap satu bulan sekali untuk mengecek dan mencocokan kondisi fisik obat dengan kartu stok. Dengan melakukan stock opname juga dapat diketahui waktu kadaluarsa suatu obat. Obat yang mendekati kadaluarsa dapat diinformasikan kepada Apoteker Penanggung Jawab agar dapat dipergunakan terlebih dahulu atau bila memungkinkan dapat dikembalikan kepada distributor. Hal ini sudah sesuai dengan Dirjen Binakefarmasian dan Alat Kesehatan RI (2010) yaitu stock opname diperlukan untuk kebutuhan audit dan perencanaan yang wajib dilakukan. 
Kartu stok di gudang farmasi merupakan pencatatan yang yang dilakukan setiap terjadi mutasi sediaan farmasi (penerimaan, pengeluaran, hilang, rusak/kadaluarsa). Buku Defekta merupakan pencatatan mengenai permintaan dan pengiriman obat dari gudang farmasi ke apotek. Obat yang diminta oleh apotek dicatat pada buku tersebut, selanjutnya bagian gudang akan farmasi akan memeriksa stok yang ada untuk memenuhi permintaan apotek. Jumlah obat yang dikirim dan sisa obat yang ada di gudang farmasi akan dicatat di buku tersebut. Hal ini sesuai dengan Dirjen Binakefarmasian dan Alat Kesehatan RI (2010) yang menjelaskan bahwa pencatatan merupakan suatu kegiatan yang bertujuan untuk memonitor transaksi perbekalan farmasi yang keluar dan masuk di Apotek.

Pelayanan penyediaan obat di Klinik Apotek Dharma sering tidak sesuai dengan kebutuhan atau permintaan. Hal ini disebabkan karena stok obat yang tidak cukup (stok out) untuk memenuhi permintaan tersebut. Kekosongan obat ini menyebabkan tidak terpenuhinya permintaan pasien sehingga menyebabkan pasien menjadi kecewa atau harus mencari ke apotek lain yang tentunya mengeluarkan biaya yang lebh besar atau pemborosan dibandingkan dengan membeli di distributor dan juga menyebabkan kerugian. Seharusnya menurut Anief, M (2014) sediaan farmasi yang dibutuhkan dalam pelayanan kesehatan harus tersedia dalam jumlah, kualitas dan waktu yang tepat (sesuai dengan kebutuhan) dengan harga serendah mungkin. Hal ini menunjukkan bahwa kegiatan pelayanan penyediaan sediaan farmasi di Klinik Apotek Dharma belum berjalan dengan baik sesuai dengan teori yang ada.
Kekosongan obat tersebut sebenarnya dapat dihindari jika dilakukan perencanaan /penentuan kebutuhan perbekalan farmasi secara terpadu. Hal ini seperti yang disarankan oleh Dirjen Binakefarmasian dan Alat Kesehatan RI (2010) yaitu dengan koordinasi dan proses perencanaan untuk pengadaan sediaan farmasi secara terpadu diharapkan sediaan farmasi khususnya obat-obatan yang direncanakan dapat tepat jenis, tepat jumlah, tepat waktu dan tersedia pada saat yang dibutuhkan.

Dalam melakukan perencanaan obat di Klinik Apotek Dharma juga dipengaruhi oleh pergerakan obat yaitu fast moving atau slow moving. Namun dalam menentukan obat golongan fast moving atau slow moving tidak pernah dilakukan perhitungan, melainkan hanya berdasarkan pengalaman atau perkiraan. Belum adanya pembagian obat berdasarkan nilai klasifikasi vital, esensial atau non esensial (VEN) atau klasifikasi ABC berdasarkan nilai investasi dan nilai pakai obat menyebabkan jumlah obat yang dipesan di Klinik Apotek Dharma belum dibuat perencanaannya juga belum diterapkannya metode EOQ dan ROP, sehingga dalam menentukan jumlah obat yang dipesan dan waktu pemesanan obat hanya berdasarkan perkiraan saja atau akibatnya dapat terjadi kelebihan obat yang berakibat obat mengalami kadaluarsa atau rusak atau kekurangan obat (stok out) yang dapat menyebabkan kerugian bagi pihak Klinik Apotek Dharma.

Untuk itu bagian pengadaan dan gudang farmasi Klinik Apotek Dharma memerlukan perhitungan sesuai dengan data riil kebutuhan pasien mengenai jumlah pemesanan dan waktu pemesanan yang tepat agar obat dapat tersedia dalam jumlah dan waktu 
yang tepat serta diperoleh dengan harga serendah mungkin. Namun sebelum menentukan jumlah dan waktu pemesananan perlu diketahui obat mana yang harus diperioritaskan untuk meningkatkan efisiensi persediaan. Menurut Satibi, et al (2015) Pengelolaan sediaan farmasi sering kali berhadapan dengan beberapa permasalahan dasar dalam persediaan yaitu seberapa banyak persediaan yang akan dipesan, kapan waktu untuk memesan dan bagaimana mengendalikan sistem persediaan (prosedur, rutinitas yang harus dipantau) dan sebuah unit pelayanan kesehatan harus dapat menjawab tiga permasalahan tersebut.

Pengelolan sediaan farmasi dan perbekalan kesehatan lainnya harus sesuai dengan ketentuan peraturan perundang-perundangan yang berlaku meliputi perencanaan, pengadaan, penyimpanan dan pelayanan. Selama ini pengelolaan persediaan farmasi Klinik Apotek Dharma sudah mengikuti peraturan perundanganundangan tetapi belum menggunakan analisis yang tepat sehingga diperlukan penelitian sehingga akan diperoleh pengendalian persediaan yang efektif dengan mengoptimalkan dua tujuan yaitu memperkecil nilai investasi pada persediaan namun tetap mampu menjual atau menyediakan berbagai produk yang benar untuk memenuhi permintaan konsumen

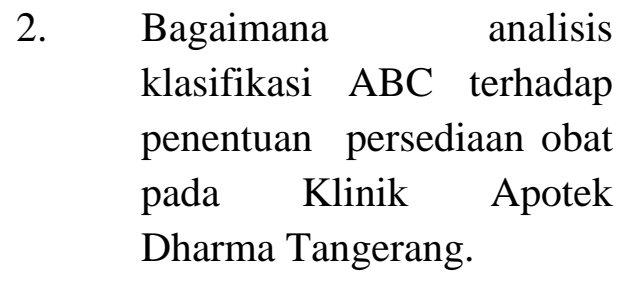

Berdasarkan analisis ABC investasi

Kelompok A dari golongan Vital, Esensial atau Non esensial merupakan persediaan yang nilai investasinya tinggi (70-90\%) yaitu untuk golongan obat vital (V) penggunaan anggaran sebesar $69,83 \%$ dari total nilai investasi obat golongan vital (V) dengan volume sediaan 17 unit (25,76\%), golongan obat esensial (E) penggunaan anggaran sebesar 70,23\% total nilai investasi obat golongan dengan volume sediaan 13 unit $(22,42 \%)$ dan golongan obat non esensial $(\mathrm{N})$ penggunaan anggaran sebesar $72,65 \%$ dari total nilai investasi obat golongan non mesensial (N) dengan sediaan volume 6 unit $(16,67 \%)$.

Kelompok B adalah persediaan yang nilai investasinya sedang (15-20\%) yaitu untuk golongan obat vital (V) penggunaan anggaran sebesar 20,16\% dari total nilai investasi golongan obat vital dengan volume sediaan 18 unit (27,27\%), golongan obat esensial (E) penggunaan anggaran sebesar 19,24\% dari total nilai investasi golongan obat esensial dengan volume sediaan 14 unit $(24,14 \%)$, golongan obat non esensial (N) penggunaan anggaran sebesar $19,44 \%$ total nilai investasi golongan obat non esensial dengan volume sediaan 7 unit (17,88\%).

Kelompok $\mathrm{C}$ adalah persediaan dengan nilai investasinya rendah (10-20\%) yaitu untuk golongan obat vital (V) penggunaan anggaran sebesar $10,01 \%$ dari total nilai investasi obat golongan vital dengan volume sediaan 31 unit (46,97\%), golongan esensial (E) penggunaan anggaran sebesar 10,53\% dari total nilai investasi dengan volume sediaan 31 unit $(53,44 \%)$, golongan obat non esensial $(\mathrm{N})$ penggunaan anggaran sebesar 9,48\% dari total nilai investasi obat golongan non esensial dengan volume sediaan 23 unit (63,89\%).

Berdasarkan analisis ABC nilai pakai Kelompok A dari obat golongan vital (V) ada 17 unit ( 25,76\% ) dengan 
jumlah pemakaian 5235 unit (67,79\%) per tahundari total pemakaian obat golongan vital (V). Kelompok A dari obat golongan esensial (E) ada 15 unit $(25,86 \%)$ dengan jumlah pemakaian 1706 unit $(69,12 \%)$ per tahun dari total pemakaian obat golongan esensial. Kelompok A dari obat golongan non esensial (N) ada 7 unit (19,44\%) dengan jumlah pemakaian sebanyak 936 unit $(70,86 \%)$ per tahun dari total pemakaian obat golongan non esensial (N). Obat yang termasuk kelompok A dari golongan obat vital, esensial atau non esensial adalah obat dengan pemakaian tinggi (fast moving) dan juga volume yang tinggi.

Kelompok B dari golongan obat vital (V) ada 19 unit (28, 79\%) dengan jumlah pemakaian 1559 unit (20,78\%) per tahun dari total pemakaian obat golongan vital. Kelompok B dari obat golongan esensial (E) ada 18 unit (31,03\%) dengan jumlah pemakaian 529 unit $(21,43 \%)$ per tahun dari total pemakaian obat golongan esensial. Kelompok B dari obat golongan non esensial (N) ada 10 unit (27,78\%) dengan jumlah pemakaian 259 unit (19,53\%) per tahun dari total pemakaian obat golongan non esensial. Obat yang termasuk kelompok B ini termasuk golongan moderate denagan volume dan nilai pakai yang sedang.

Kelompok C dari obat golongan vital (V) ada 30 unit $(45,45 \%)$ dengan jumlah pemakaian 707 unit (9,43\%) per tahun dari total pemakaian obat golonngan vital,. Kelompok C dari obat golongan esensial ada 25 unit $(43,10 \%)$ dengan jumlah pemakaian $233(94,44 \%)$ per tahun dari total pemakaian obat golongan esensial. Kelompok $\mathrm{C}$ dari obat golongan non esensial (N) ada 19 unit (52,78\%) per tahun dengan jumlah pemakaian 127 unit $(9,61 \%)$ dari total obat golongan non esensial. Obat kelompok C ini termasuk obat golongan slow moving dengan jumlah banyak tetapi tingkat pemakaian nya rendah.

3. Bagaimana metode analisis vital, esensial dan non esensial (VEN) terhadap penentuan persediaan obat pada Klinik Apotek Dharma Tangerang

Metode analisis VEN merupakan metode penggelompokkan obat berdasarkan kepada dampak tiap jenis obat terhadap kesehatan. Semua jenis obat yang direncanakan dikelompokkan ke dalam tiga kategori yaitu (Febriawati, H, 2013) yaitu vital (V) yaitu obat-obat yang harus tersedia untuk melayani permintaan guna penyelamatan hidup manusia, atau untuk pengobatan karena penyakitnya tersebut menyebabkan kematian, esensial (E) yaitu obat-obatan yang banyak diminta untuk digunakan dalam tindakan atau pengobatan penyakit terbanyak yang ada disuatu daerah atau rumah sakit dan non esensial (N) yaitu obat-obat pelengkap agar tindakan atau pengobatan menjadi lebih baik.

Dari sekitar 160 obat yang digunakan dalam pelayanan kefarmasian di Klinik Apotek Dharma berdasarkan keputusan antara Apoteker Pengelola Apotek sebagai Penanggung Jawab Apotek dan Pemilik Sarana Klinik Apotek Dharma yang juga merupakan seorang dokter yang berperan dalam pengadaan sediaan obat maka dapat diklasifikasikan 66 jenis obat termasuk dalam golongan vital (V) yaitu $41,25 \%$, dimana yang termasuk golongan obat ini harus tersedia dalam waktu kurang dari 48 jam, 58 jenis obat termasuk golongan esensial (E) yaitu 36,25 \% dimana yang termasuk golongan obat ini bekerja pada sumber 
penyakit dan kekosongannya dapat ditolerir dalam waktu sampai 48 jam dan 36 jenis obat termasuk golongan Non Esensial (N) yaitu 22,5\% dimana yang termasuk golongan ini adalah merupakan obat penunjang yang kekosongannya dapat ditolerir lebih dari 48 jam.

4. Bagaimana sistem penentuan persedian obat di Klinik Apotek Dharma Tangerang

Berdasarkan analisis ABC Indeks Kritis

Kelompok A ada 57 unit (36\%) dari obat golongan vital (V) dan esensial dengan Nilai Indek Kritis tinggi yaitu 9-12. Obat-obat dalam kelompok A ini tidak boleh terjadi kekosongan mengingat efek terapinya terhadap pasien. Kelompok B ada 79 unit (49\%) dari obat golongan vital, esensial dan non esensial dengan Nilai Indeks Kritis sedang yaitu 6-8. Kekosongan obat kelompok B ini dapat ditoleransi tidak lebih dari 24 jam dengan frekuensi pemesanan lebih jarang. Kelompok C ada 24 unit (15\%) dari obat golongan esensial (E) dan non esensial (N) dengan Nilai Indeks Kritis rendah 4-6. Kekosongan obat kelompok C dapat lebih 24 jam, dengan frekuensi pemesanan lebih jarang, disesuaikan dengan kebutuhan dan dana yang tersedia.

Berdasarkan metode Economic Order Quantity (EOQ) jumlah pemesanan optimum untuk golongan obat vital 66 unit bervariasi dari yang terendah yaitu EOQ nya 1 (2 unit) dan tertinggi EOQ nya 105 (1 unit) golongan obat esensial (E) bervariasi dari yang terendah nilai EOQ nya 1 (3 unit) dan yang tertinggi EOQ nya 41 (1unit ). Golongan obat non esensial $(\mathrm{N})$ juga bervariasi dari yang terendah 1 (3 unit) dan yang tertinggi 58 (I unit ).

Berdasarkan metode Reorder Point (ROP) dengan mempertimbangkan safety stock diperoleh titik pemesanan kembali atau waktu pemesanan kembali dari 160 unit obat bervariasi. Untuk golongan obat vital yaitu 0-10 unit. Untuk golongan obat esensial yaitu $0-4$ unit. Untuk golongan obat non esensial $0-3$ unit.

\section{SARAN}

1. Perlu adanya sistem informasi untuk dapat menghasilkan sistem informasi mengenai jumlah pemakaian setiap obat, baik perbulan, triwulan atau tahunan agar memudahkan dalam menyusun kebutuhan persediaan obat. Seperti penggunakan sistem informasi manajemen Apotek yang terintegrasi ke setetiap pelayanan sehingga memeprmudah dalam pengawasan, pengadaan dan pengendalian obatobatan.

2. Perlu diterapkannya analisis VEN untuk memberikan informasi yang akurat dalam pengendalian obatobat berdasarkan dampaknya terhadap kesehatan sehingga dalam pengadaan obat di Klinik Apotek di perlukan formularium atau standar terapi yang dievaluasi setiap tahun.

3. Perlu diterapkannya metode analisis ABC obat 
berdasarkan besarnya nilai investasi, sehingga obat yang memakai anggaran investasi yang besar dapat lebih diperhatikan.

4. Perlu diterapkannya metode analisi ABC berdasarkan besarnya nilai pakai, sehingga obat yang nilai pakainya lebih tinggi lebih diperhatikan pengadaannnya

5. Perlu diterapkannya metode Analisis ABC Indeks Kritis yang metupakan metode kombinasi antara metode analisis $\mathrm{ABC}$ nilai investasi, $A B C$ nilai pakai dan analisis vital (V), esensial (E) dan non esensial (N) untuk memberikan prioritas yang berbeda terhadap setiap golongan obat karena obat dengan nilai investasi, nilai

\section{DAFTAR PUSTAKA}

Anief, M. (2014). Manajemen Farmasi, Universitas Gajah Mada Press. Cetakan VI, 2014, 10-22.

Bachrun E.,(2017), Efektifitas Metode ABC (Activity Based Costing) Dalam Analisis Perencanaan Obat JKN di Puskesmas Dagangan Kabupaten Madiun. Jurnal Kesehatan, 8(2), 250. https://doi.org/10.26630/jk.v $8 \mathrm{i} 2.493$.

Balai Besar Pengawas Obat dan Makanan. Laporan Tahunan Balai Besar Pengawas Obat dan Makanan tahun 2019, Serang, Banten. pakai tinggi dan dampaknya terhadap kesehatan yang tinggi memerlukan sistem pengendalian yang ketat dari pada obat yang memiliki nilai investasi dan nilai pakai yang rendah.

6. Perlu diterapkanya metode EOQ untuk menghindari terjadinya kekosongan obat atau obat yang berlebih (kadaluarsa) karena selama ini Klinik Apotek Dharma sering mengalami kekosongan obat, obat berlebih yang berakibat obat menjadi rusak (kadaluarsa).

7. Perlu diterapkannya metode Reorder Point (ROP) dan Safety Stock (SS) sehingga titik pemesanan ulang dan stok pengaman dari unit obat dapat dikendalikan.

Departemen Kesehatan RI, 2010. Pedoman Teknis Pengadaan Obat Publik Dan Perbekalan Kesehatan Untuk Pelayanan Kesehatan Dasar. Jakarta.

Febriawati, H., Manajemen Logistik Rumah Sakit. Gosyen Publishing. Cetakan I, 2013, hal 87-99.

Heizer, J. dan Render, B. 2016. Prinsip - Prinsip Manajemen Operasi,. Edisi IX Salemba Empat, Jakarta, 553-586

Kementerian Kesehatan RI, 2010, Dirjen Binakefarmasian dan Alat Kesehatan, Pedoman Pengelolaan Perbekalan Pelayanan Kefarmasian, Jakarta

Kementerian Kesehatan RI. 2014. Peraturan Kementerian 
Kesehatan Republik Indonesia Nomor 35 tentang Standar Pelayanan Kefarmasian Apotek, Jakarta.

Kementerian Kesehatan RI. 2016. Peraturan Menteri Kesehatan Repbublik Indonesia Nomor 73 tentang Standar Pelayanan Kefarmasian di Apotek, Jakarta
Kementerian Kesehatan RI. 2019. Pedoman Penyusunan Rencana Kebutuhan Obat Dan Pengendalian Persediaan Obat di Rumah Sakit, Jakarta.

Satibi, et al. 2018. Manajemen Apotek. Gadjah Mada University Press. Cetakan II. 27-31, 4. 